\title{
Application of Magnetic Survey in the Investigation of Iron Ore Deposits and Shear Zone Delineation: Case Study of Mutomo-Ikutha Area, SE Kenya
}

\author{
Aaron K. Waswa' ${ }^{1}$, Christopher M. Nyamai ${ }^{1}$, Eliud Mathu' ${ }^{2}$, Daniel W. Ichang'i1 \\ ${ }^{1}$ Department of Geology, University of Nairobi, Nairobi, Kenya \\ ${ }^{2}$ Department of Geological Sciences, SE Kenya University, Kitui, Kenya \\ Email: aaronwaswa@gmail.com
}

Received 15 May 2015; accepted 20 July 2015; published 27 July 2015

Copyright (C) 2015 by authors and Scientific Research Publishing Inc.

This work is licensed under the Creative Commons Attribution International License (CC BY). http://creativecommons.org/licenses/by/4.0/

(c) (i) Open Access

\section{Abstract}

The main objective of this research was to use ground magnetic survey to delineate shear zone and iron ore deposit within the Neoproterozoic rocks of Mutomo-Ikutha area of south eastern Kenya. Total field magnetic data was recorded by using high resolution proton precision geometric magnetometer which recorded total components of the ground magnetic anomaly data running through sixteen traverses. The field data was qualitatively and quantitatively interpreted and the results gave values for the total component measurements of ground magnetic anomaly that varied between a minimum negative peak value of about 250 nanoTesla and a maximum of about 1000 nanoTesla. 550 nanoTesla was considered to be threshold of the iron mineralization within the area. The results indicated that the western part of Mutomo-Ikutha was sheared, faulted and contained iron ore mineralization trending in the north-south direction. Areas with high anomalous values were geochemically proven to contain magnetite.

\section{Keywords}

Iron Ore, Magnetic Survey, Neoproterozoic, Mutomo-Ikutha

\section{Introduction}

The use of magnetic data is a geophysical exploration technique based on mapping the subsurface distribution of magnetic minerals (oxides or sulphides). This technique can be a valid approach to mineral exploration either 
directly for mineral deposits containing magnetic minerals (e.g. magnetite, hematite, pyrhotite) or indirectly for the ones spatially associated with, for example, faults. Advances in spatial controls using global positioning systems (GPS) have not only reduced the survey costs but also increased data accuracy.

Total magnetization of rock is a vector sum of the two components: 1 ) induced magnetization (proportional in magnitude and generally parallel to the earth's ambient field); and 2) remnant magnetization (which has direction and intensity dependent on the origin and geological history of the rock). The intensity of induced magnetization is related to the ambient field through the magnetic susceptibility of the rock considered (Hildenbrand et al. [1]). This magnetic susceptibility constant is directly proportional to the modal mineral composition and chemistry of the rock.

Rocks have widely varying magnetic properties (Carmichael [2]; Clark [3]). At the regional scale, magnetic highs are commonly associated with major igneous provinces in crystalline basement. By contrast, magnetic lows often occur in areas dominated by thick sedimentary basins (Hildenbrand et al. [1]) or where, for example, igneous rocks are altered and magnetite is replaced by hematite when hydrothermal fluids have migrated along faults. Telford et al. [4] emphasized that magnetic response observed in magnetic anomaly maps was influenced by the geometry and depth of the magnetic bodies, their azimuth with regard to magnetic north, and the inclination of the magnetic field at the latitude of the survey. In the neighbourhood of mineral deposits, mineralogical variety and thermal history related to mineral deposit can subsequently affect magnetic properties. The degree of oxidation, alteration, weathering, and metamorphism also affects the magnetic properties of the rock (Hildenbrand et al. [1]). All these combined factors concur to generate complex sections of magnetic properties for ground magnetic survey in Mutomo-Ikutha area.

The main objective of this research was to investigate and determine the surface and subsurface distribution of the iron ore mineralization within the shear zone so as to establish its economic potential.

The study area is located between longitudes $38^{\circ} 4^{\prime} \mathrm{E}$ to $38^{\circ} 20^{\prime} \mathrm{E}$ and latitudes $1^{\circ} 48^{\prime} \mathrm{S}$ to $2^{\circ} 8^{\prime} \mathrm{S}$ in South Kitui within the Kitui County in the republic of Kenya (Figure 1).

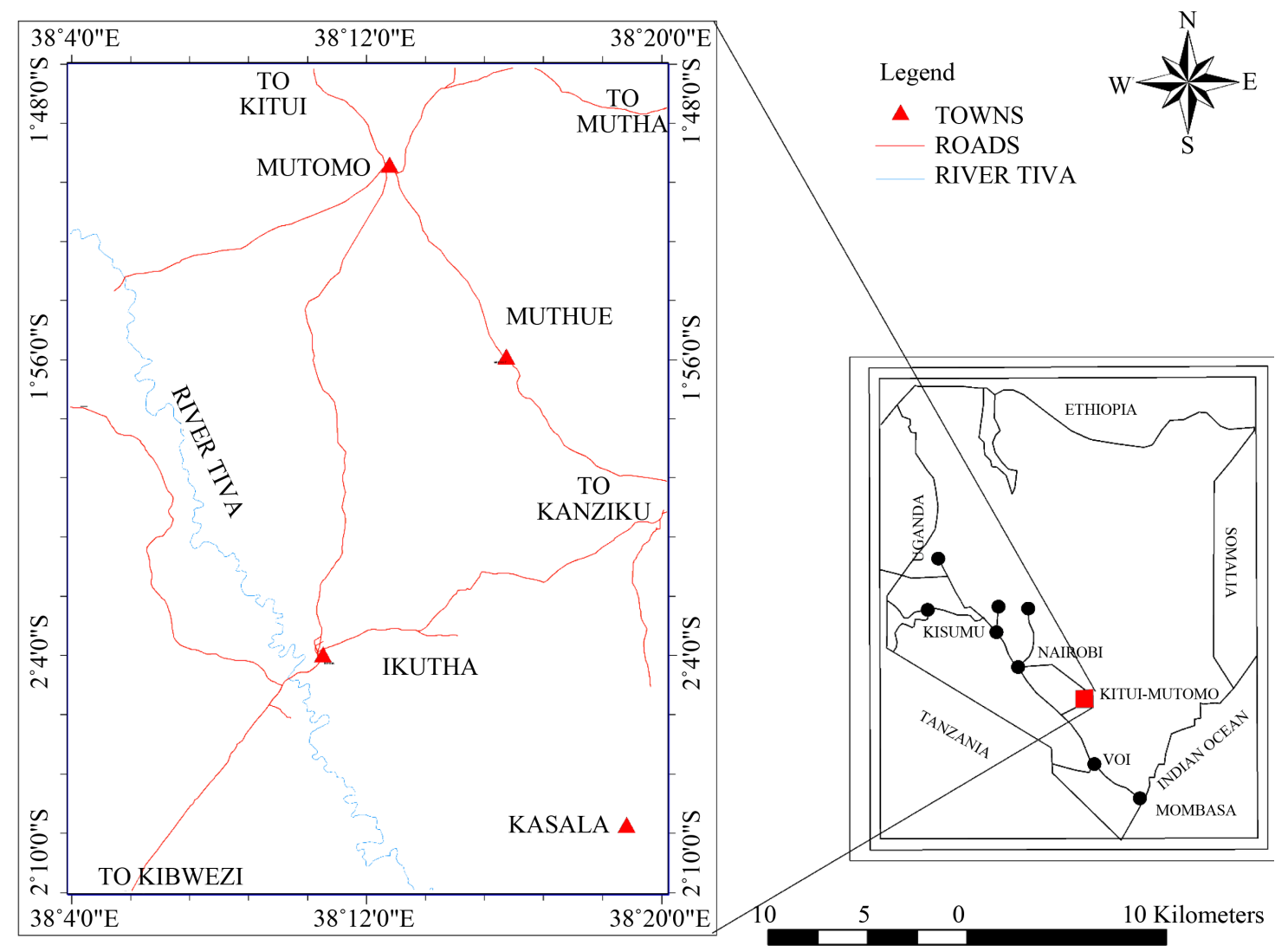

Figure 1. The map showing the area of the project. Major towns within the area include Mutomo and Ikutha. 


\section{Geology of the Study Area}

Mutomo-Ikutha area occurs within the Neoproterozoic Mozambique Belt. This belt is a major N-S trending metarmophic and lithotectonic domain that extends along the Eastern Coast of Africa, as well as in Saudi Arabia, Madagascar, India and Sri Lanka. It was first defined by Holmes [5], mostly on metamorphic and structural criteria. The Mozambique is a Neoproterozoic Belt (900 to 550) which is affected by the Pan African tectonothermal event about $650 \mathrm{Ma}$, as suggested by (Kennedy [6]; Kazmin [7]; Kröner [8]; Cartier [9]) who considered it as a major phase of division of the African continent linked to the development of mobile belts. The Pan African event encompasses a wide time span from 650 to 500 million years. Mozambique Belt is considered as an orogen resulting from the oblique collision between two Gondwana fragments (Muhongo [10]; Burke and Derwey [11]; Gass [12]; Key et al. [13]; Kröner [8]). Stern [14] proposed its name to be changed to East African Orogen. The geology, structures and tectonic the history of the Mozambique Belt in Kenya have been reviewed by Waswa et al. [15]. Other reviewers of this belt include Mathu and Tole [16]; Mathu [17]; Mathu et al. [18]; Mathu et al. [19]; Gaciri et al. [20]; Biyajima et al. [21]; Suwa et al. [22]; Opiyo-Aketch and Nyambok [23]; Hackman et al. [24]; Mosley [25]; Nyamai [26]-[32]; Saggerson [33]; Walsh [34].

The Mutomo-Ikutha area is a medium- to high-grade gneiss terrane which comprises predominantly amphibolite-grade metasediments (pelitic, semi-pelitic, quartzo-felspathic, calc-silicate rocks, quartzite and marble migmatizedparagneisses), metavolcanics and intrusives (see Figure 2).

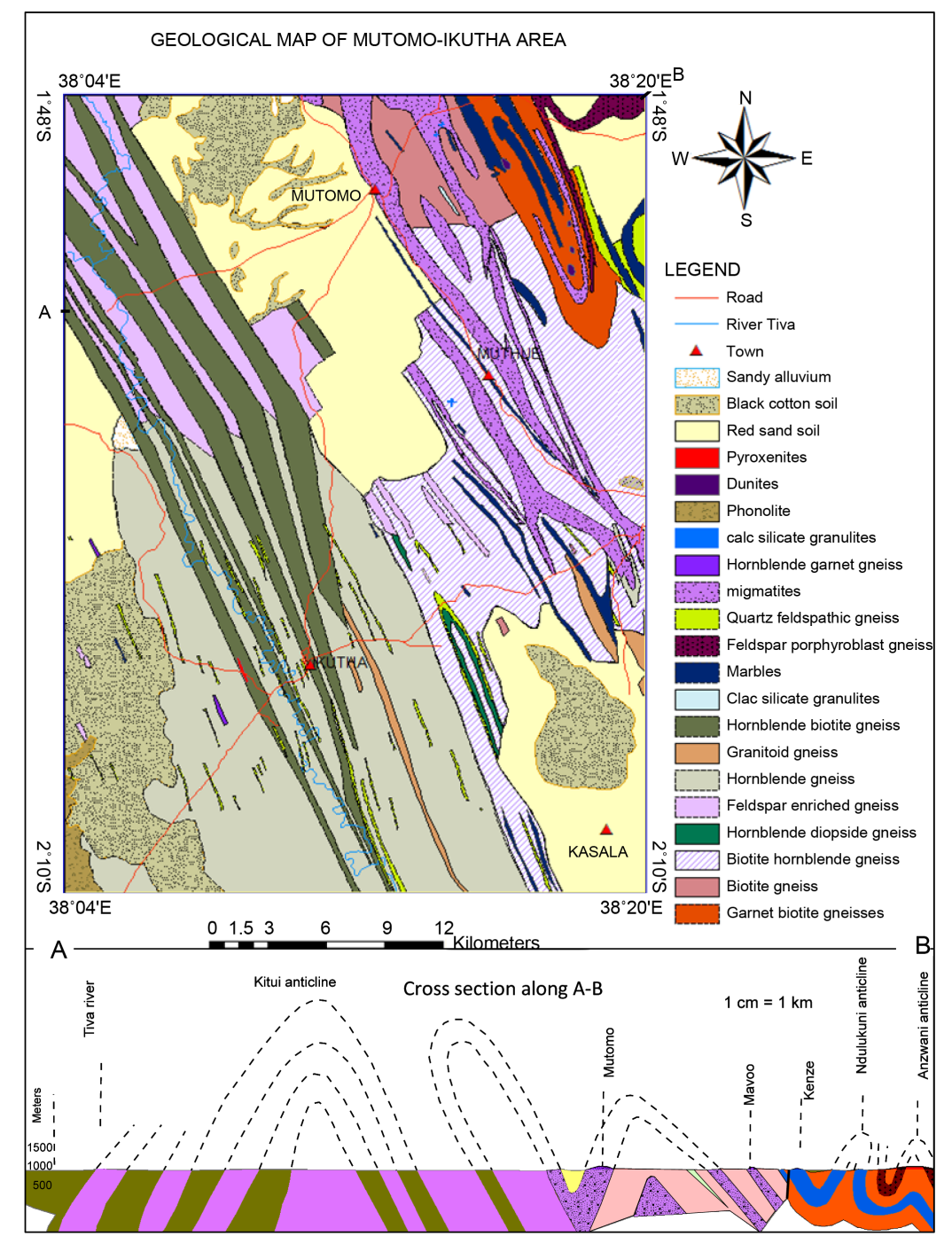

Figure 2. Geological map of Mutomo-Ikutha area (after Waswa et al., 2015). 
The following mineral assemblages are represented by the lithologies within Mutomo-Ikutha;

- Hornblende + Quartz + Biotite + Magnetite + Apatite \pm Plagioclase, Microcline

- Quartz + Plagioclase \pm hornblende, biotite, muscovite, Magnetite and apatite

- Hornblende + Quartz + Plagioclase + Biotite \pm Epidote, apatite, Iron ore, Garnet, Zircon

- Hornblende + Hypersthene + Quartz + Plagioclase + Diopside + Apatite + Biotite + Magnetite

- Hornblende + Quartz + Plagioclase + Myrmekite + Biotite + Diopside \pm Apatite, zircon, sericite, iron ore)

- Plagioclase + Hornblende \pm Biotite, Diopside, Hypersthene, Calcite, Sphene, Apatite, Magnetite.

\section{Methodology}

Geophysical investigation utilizes the measurements of physical quantities that are made at or above the ground surface and are used to investigate concealed geology. Proton magnetometer was used in this investigation. The subsurface structures in a part of the southern part of Ikutha area were estimated by the interpretation of ground magnetic data. Magnetic survey was used to delineate magnetic lineaments, analyze its relationship to tectonic fabric and estimate the depth of perturbing body source.

\subsection{Magnetic Data Acquisition}

Total intensity magnetic field measurements were carried out with MP2 SCINTREX proton precession magnetometer made by Scintrex Company of Canada with one nanoTesla (nT) sensitivity (Figure 3). The same magnetometer was used for base station recordings to apply the diurnal variation correction as well as taking field measurements. Magnetic surveys are based on the premise that a target is limited in space and has a different physical property (e.g. magnetic susceptibility), from the surrounding formation. Unlike gravity surveying, however, the variation in magnetic susceptibility for various rock types is orders of magnitude greater than the variation in density for the same rock types. Thus, even knowing the types of rocks in a specific area does not provide sufficient information to constrain susceptibilities. Like density contrast, variations in susceptibility tradeoff strongly with other model parameters. Therefore, if susceptibility, or other model parameters, cannot be constrained from different observations, it is difficult to make quantitative estimates of the geologic structure based on magnetic observations alone.

In a particular survey, additional constraints were applied that allowed the magnetic observations to be used in a quantitative fashion. This information was derived from other separate data sets, for example, formation layering from geological mapping. The general trend of the rock units was in the northwest direction. A magnetic survey was designed to estimate the spatial extent of the structure and its susceptibility by in-lab forward

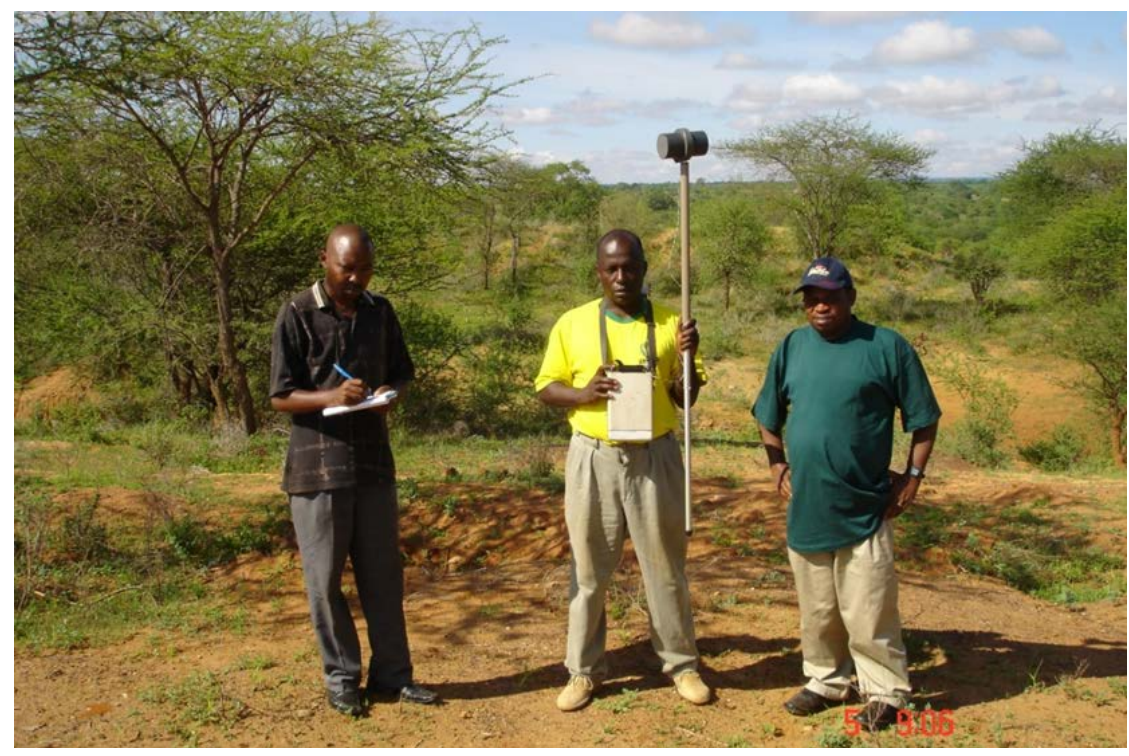

Figure 3. Ground magnetic survey in Mutomo-Ikutha area using Proton precession magnetometer. 
modeling. In planning the magnetic survey, the noise was predicted from sources not of interest in the survey, estimated the standard deviation of the random (operator and instrument) noise, calculated the shape of the signal (the theoretical anomaly produced by the assumed source), then decided whether the signal generated by the target of interest was above the noise level that allowed a meaningful interpretation to be conducted.

The Magnetic survey orientation in Mutomo-Ikutha area was in the northeast-southwest profile across the general strike of the rock units in the area. Survey was carried out at an interval of $20 \mathrm{~m}$ along each profile and $250 \mathrm{~m}$ from one profile to the next. MP2 SINTREX proton precession magnetometer was used to carry out the survey (Figure 4). Readings taken included position coordinates altitude, time and magnetic variations in nanoTesla (nT).

\section{Magnetic Data Processing}

1) Diurnal variation correction

Variation of earth's magnetic field with time, due to the rotation of the earth and with respect to the solar wind, which may last for several hours to one day, is called diurnal variation (Riddihough [35]). In order to correct for drift or diurnal effect in the magnetic readings, a base station within the area of the survey and free from magnetic interference was selected. Repeated readings were taken approximately after every one hour of the magnetic measurement for the diurnal correction. After the data collection, the diurnal effect was calculated and the magnetic data were filtered by using Equations (1) and (2):

$$
\text { Drift }=\frac{B \text { base, } \mathrm{f}-\mathrm{B} \text { base, } \mathrm{i}}{\text { tbase, } \mathrm{f}-\text { tbase, } \mathrm{i}}
$$

where Drift is the drift of measurement in a loop; B base,f and B base,i are the final and initial total magnetic field at the base station; tbase,f and tbase,i are the final and initial time at the base station.

The drift corrected field at any station in the loop for a given day was calculated from:

$$
\text { Bdrift, } \mathrm{n}=\mathrm{Bn} \text { - } \operatorname{drift}(\mathrm{tn}-\text { tbase })
$$

where Bdrift, $\mathrm{n}$ is corrected magnetic field at the nth station in the loop; $\mathrm{Bn}$ is the total magnetic field at the nth station; tn is the measuring time at the nth station; tbase is the measuring time at the first station of the loop.

2) Removal of geomagnetic field

The regional magnetic field, often referred to as geomagnetic field, is needed to be subtracted from the acquired total magnetic field to obtain the magnetic field anomaly caused by the local source (Parasnis [36]). After subtracting the diurnal effect from the original magnetic data observed, the geomagnetic field was calculated

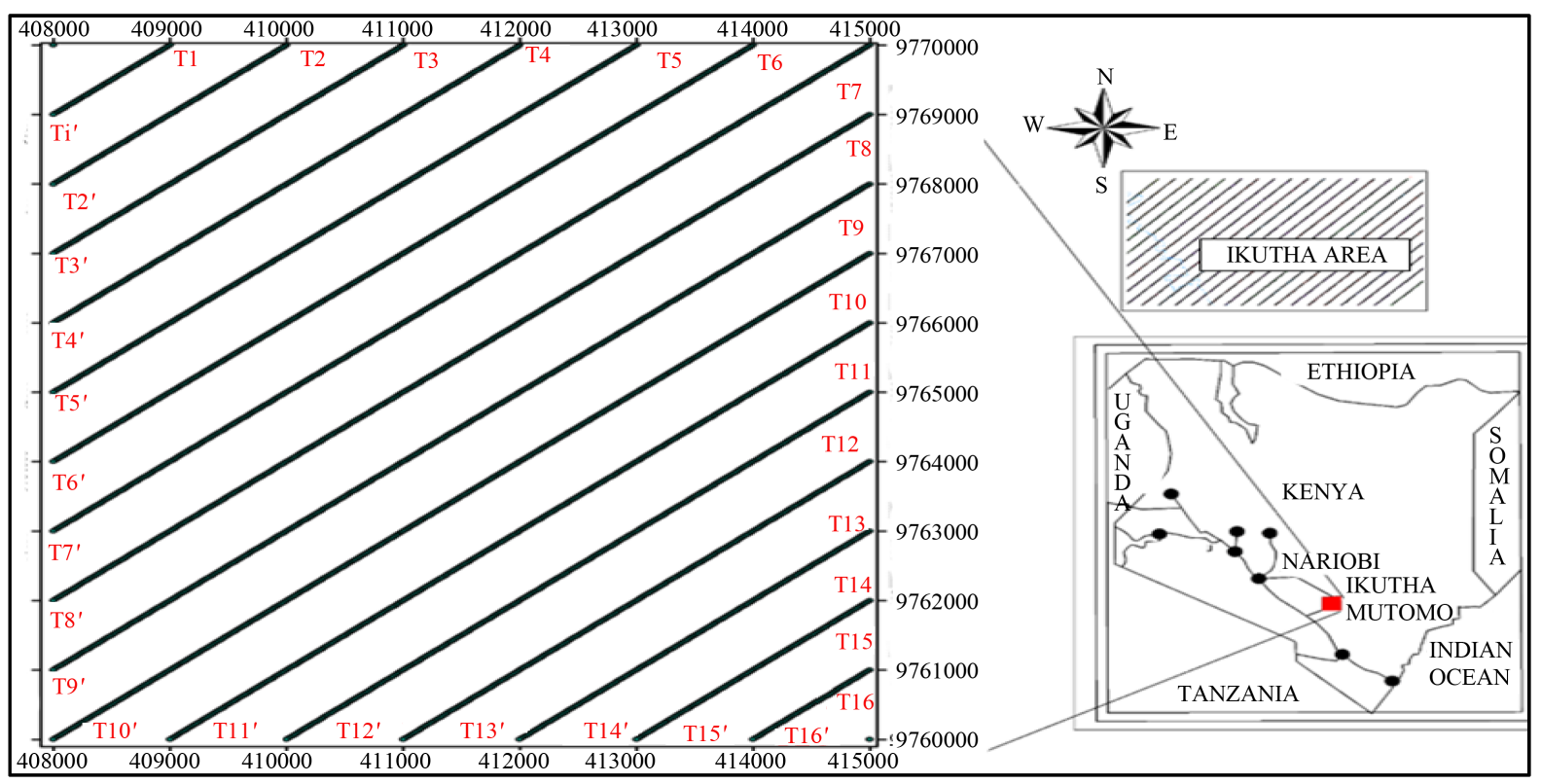

Figure 4. The map showing the location where ground magnetic survey was taken. 
by using the mathematical model of earth magnetic field called International Geomagnetic Reference Field (IGRF) model 2000-2015 in potent software, a product of Geosoft Oasis Montaj software. This model is calculated based on the dates, elevation and geographical locations (latitudes and longitudes) of the observed magnetic data with the generated average geomagnetic field of 33,000 nT, inclination of $-25.3^{\circ}$ and declination of $0.4^{\circ}$. The IGRF values were subtracted from the observed magnetic values for each station to determine the residual magnetic field due to anomalous contribution from local magnetic sources in the area.

\subsection{Geochemical Investigations}

Geochemical investigations were carried out to establish the chemical composition of the geological material that was anomalous. Geochemical survey involved fieldwork and the samples collected were analyzed using a variety of analytical techniques. Amongst the instrumental methods used in analysis included atomic absorption spectrometry (AAS) and X-ray fluorescence (XRF). Detailed identification of individual minerals was undertaken by using a polarizing microscope.

\section{Results and Discussion}

The results obtained were used to delineate the iron mineralized zone. Both 3D Euler deconvolution and 2D Euler deconvolution were used to synthesize the results. 3D Euler deconvolution utilizes XYZ ( $\mathrm{X}=$ length along $\mathrm{X}$ axis, $\mathrm{Y}=$ length along $\mathrm{Y}$ axis, $\mathrm{Z}$ = length along the $\mathrm{Z}$ axis) values to provide the subsurface geophysical information. 2D data interpretation gave information along designated profiles and the depth. The obtained values were corrected for the normal gradient of the earth's magnetic field (IGRF); the corrected magnetic values were plotted using Euler 2D and Oasis Montaj.

\subsection{Delineation of the Shear Zone Using Euler Convolution}

The high anomalous values plot on the western part of the area of survey (Figures 5-7). These values display a

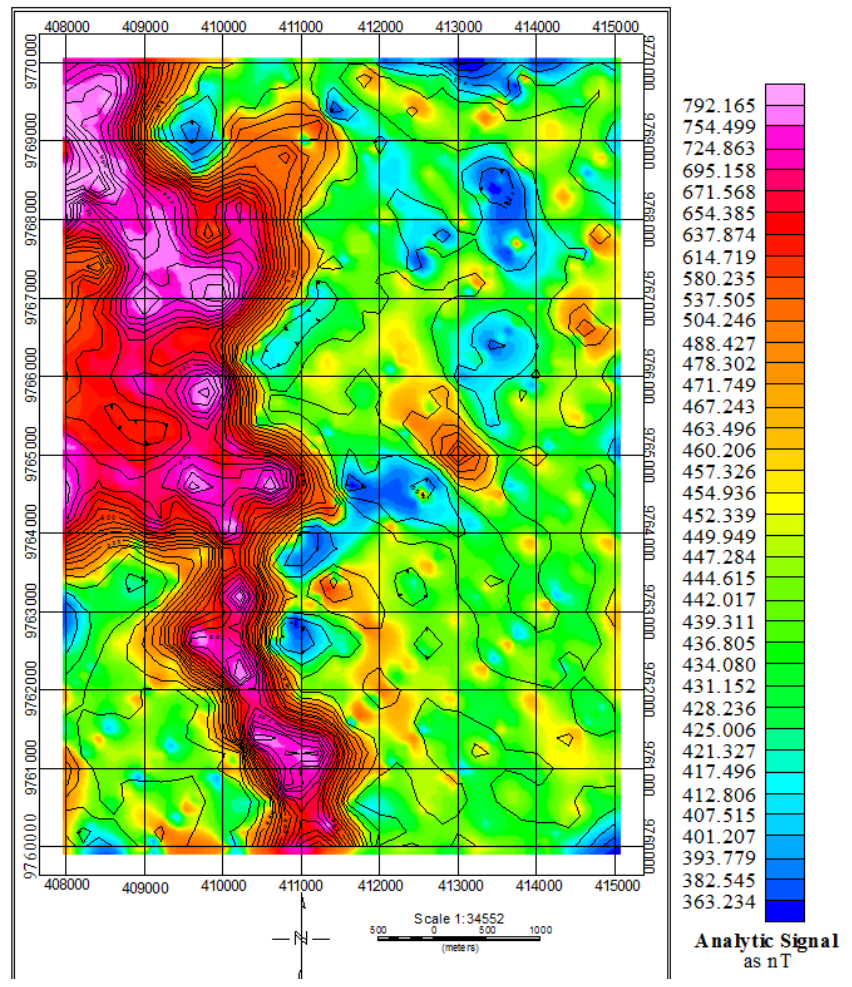

Figure 5. The figure showing the trend of Iron ore mineralization in Mutomo-Ikutha area. The boundary of the iron rich rocks is marked by the brown colour. 


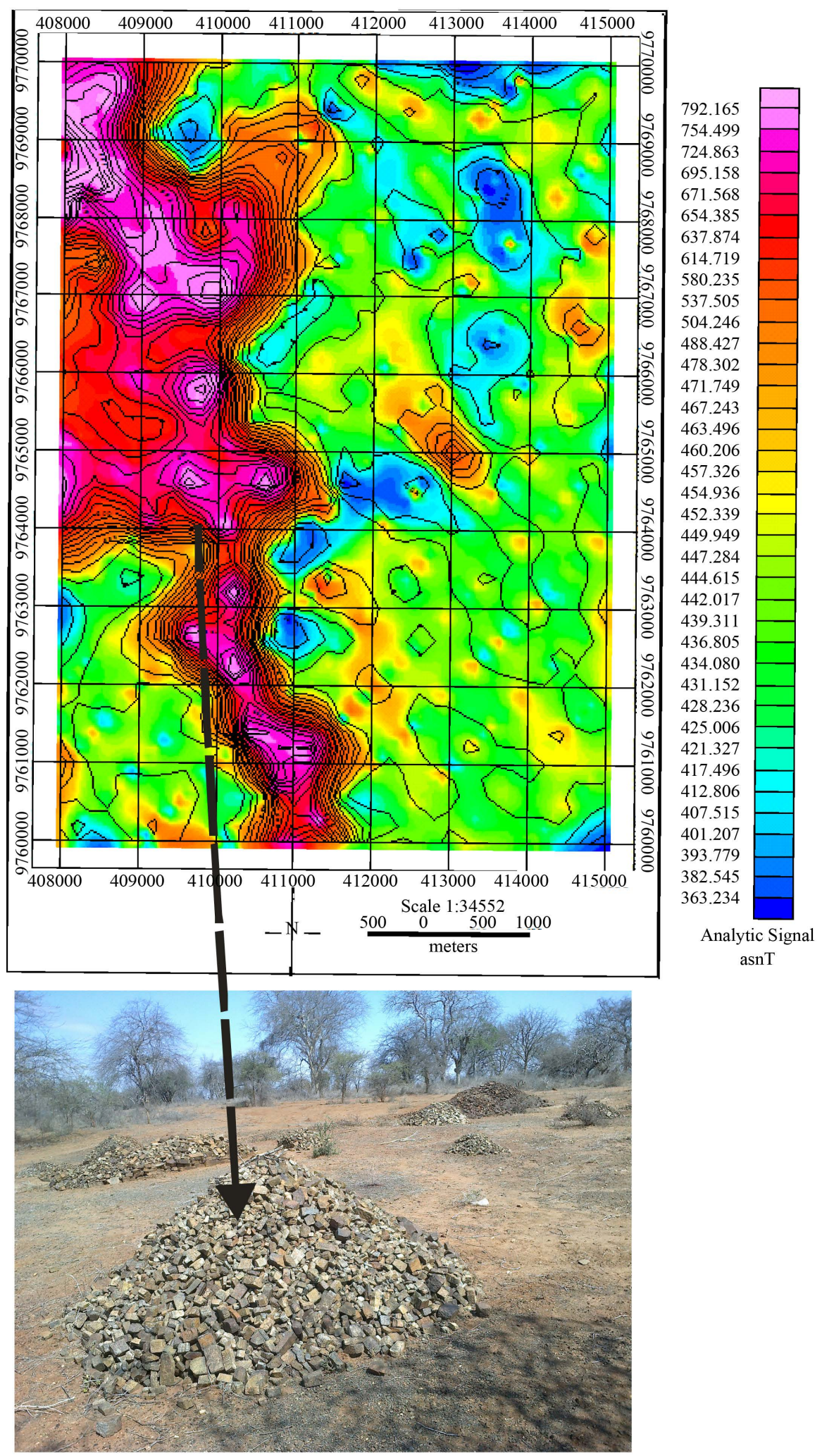

Figure 6. The contour map showing the trend of Iron ore mineralization in Mutomo-Ikutha area. The boundary of the iron rich rocks is marked by the tightly spaced contours on the western part of the research area. 


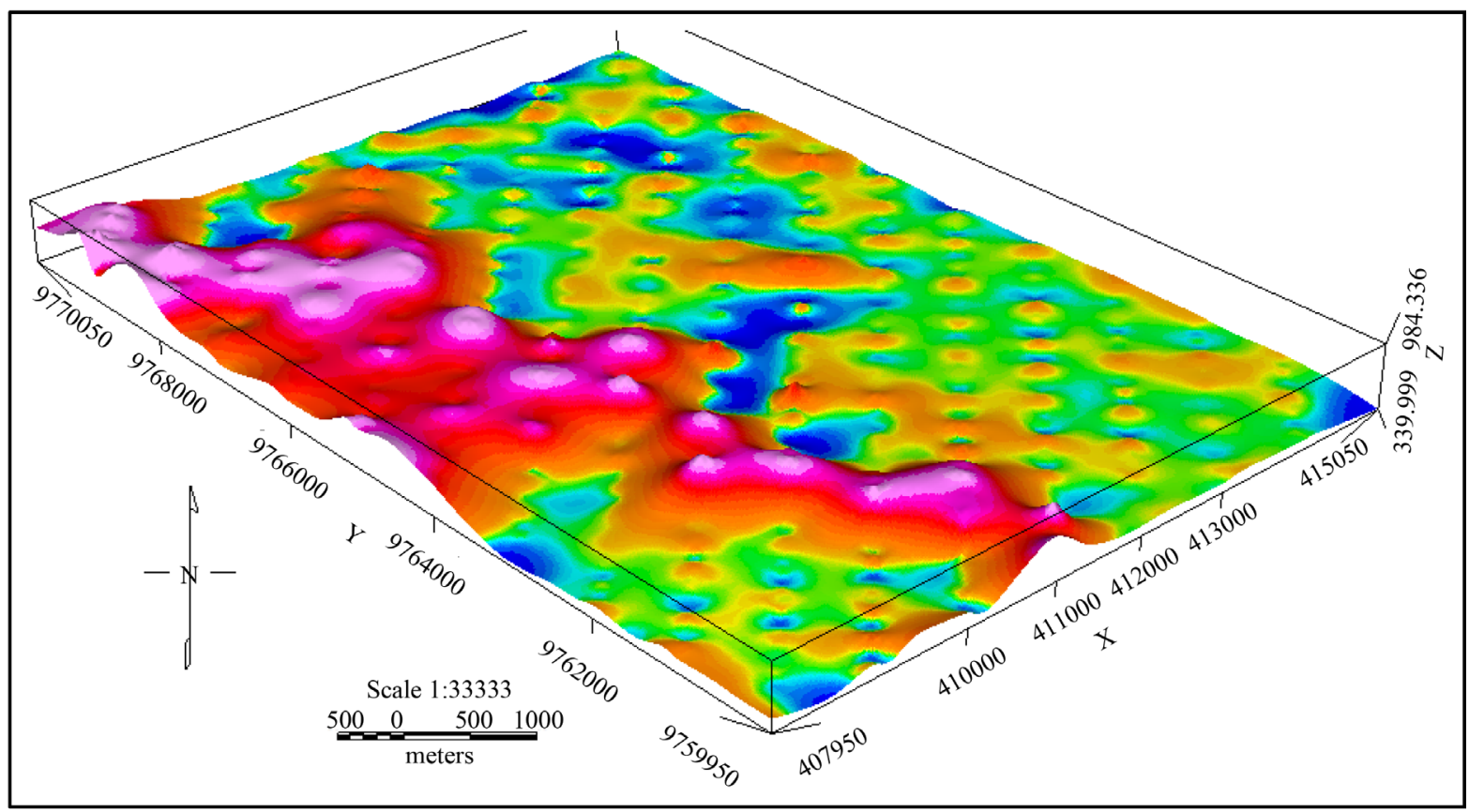

Figure 7. The 3D figure showing the trend of Iron ore mineralization in Mutomo-Ikutha area in 3D. The boundary of the iron rich rocks is marked by the red colour.

linear trend which is in the north-south direction. This trend shows that the geological body/structure having anomalous values occurs closer to the surface trending in the north-south direction. The high anomalous values range from $550 \mathrm{nT}-1000 \mathrm{nT}$.

\subsection{D Euler Data Analysis and Interpretation}

\section{Interpretation for Profile T1-T16}

High magnetic anomaly is observed from 0 - 160 meters below the surface along all the profiles (Figures 8-11), indicating the presence of a geological body which is closer to the surface. The anomalous values indicate mineralization which varies along each profile. Geological material analyzed is found to be magnetite hosted in hornblende gneiss (Table 1). Iron ore occurs in form of veins pod form, dike, sill and disseminated form. The iron ore which is magnetic is hosted in non-magnetic body (hornblende gneiss). Discontinuities of the anomalies indicate that shearing and faulting has occurred along western part of all the profiles.

\subsection{Field Proving with Laboratory Investigations}

Extensive geological, field proving and geochemical investigations were carried out for the areas with anomalous values and delineated in the studied gneisses by the magnetic survey. During the field works, the geochemical investigations revealed that the $\mathrm{Fe}_{2} \mathrm{O}_{3}$ was relatively high in the sheared gneisses. The mineralized zones were found to be mainly connected or hosted by the hornblende gneisses that followed the direction of the strong and nearly vertical shear zone striking N320W-S140E in the western part of Ikutha town.

\section{Conclusion}

The results indicate that iron mineralization in Mutomo-Ikutha has been controlled by tectonics, especially in the shear zone on the western part of the area. Chemical analysis shows that this deposit is of magnetite variety, having between $35 \%-96 \% \mathrm{Fe}_{2} \mathrm{O}_{3}, 2 \%-19 \% \mathrm{P}_{2} \mathrm{O}_{5}$ and $0.1 \%-5 \% \mathrm{TiO}_{2}$ and resembling the Apatite-Iron ores of Kiruna type. Magnetic survey has shown that Iron ore in Mutomo-Ikutha occurs from the surface to 160 meters below the surface in form of veins, dikes, sills, and pod form extending more than 10 kilometers from north- western part of the area towards the south. The iron ore deposit is structurally controlled by shear zone and hosted in 


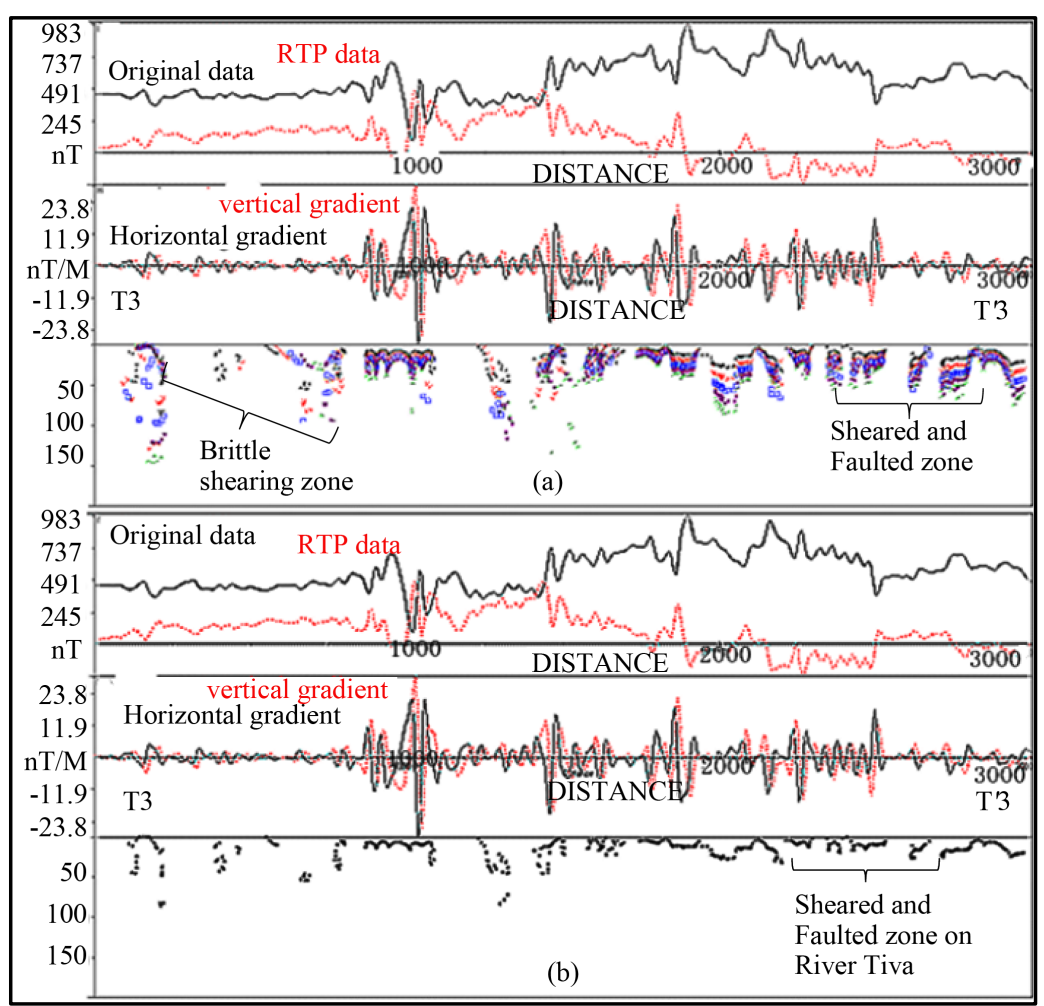

Figure 8. (a) Schematic section of profile T3-T'3 through a sheared and faulted showing the underlying mineralization; (b) structural index pseudo-section showing faulting and shearing.

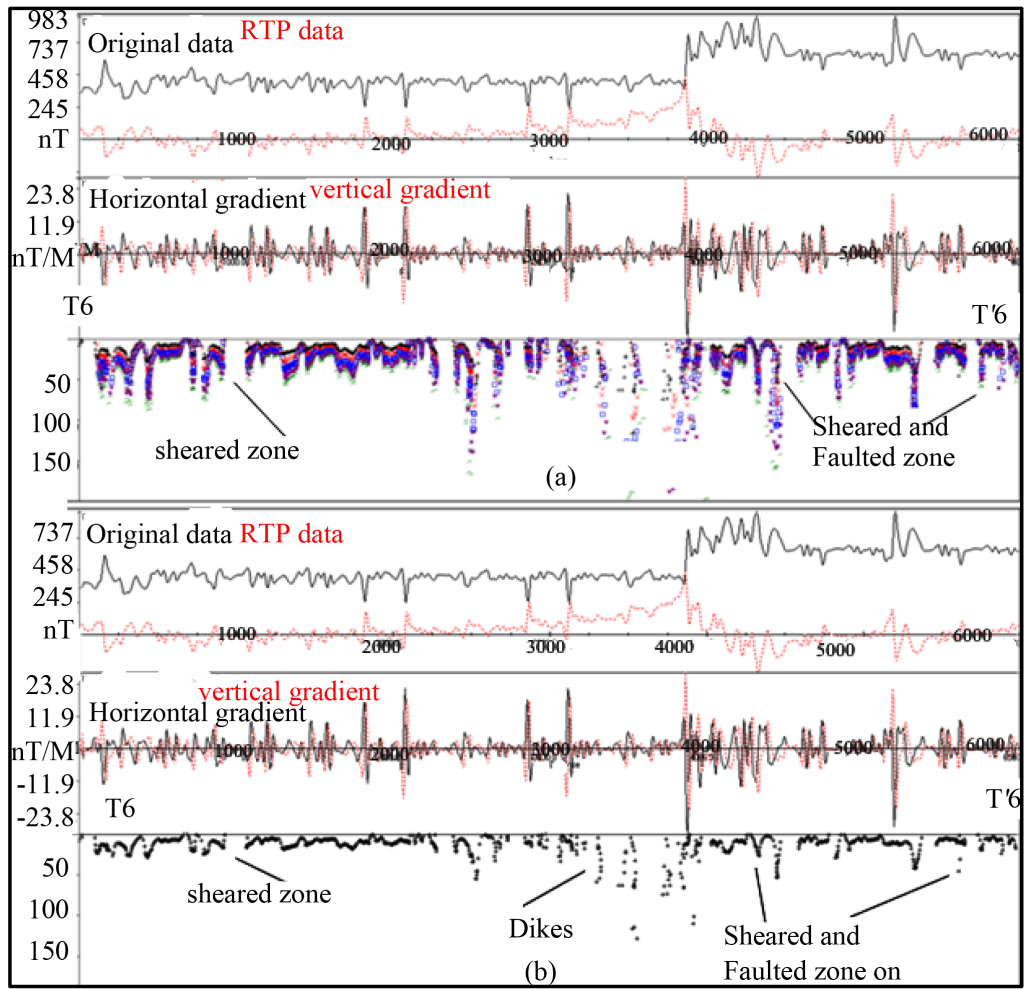

Figure 9. (a) Schematic section of profile T6-T'6 through a sheared and faulted showing the underlying mineralization; (b) structural index pseudo-section showing faulting and shearing. 


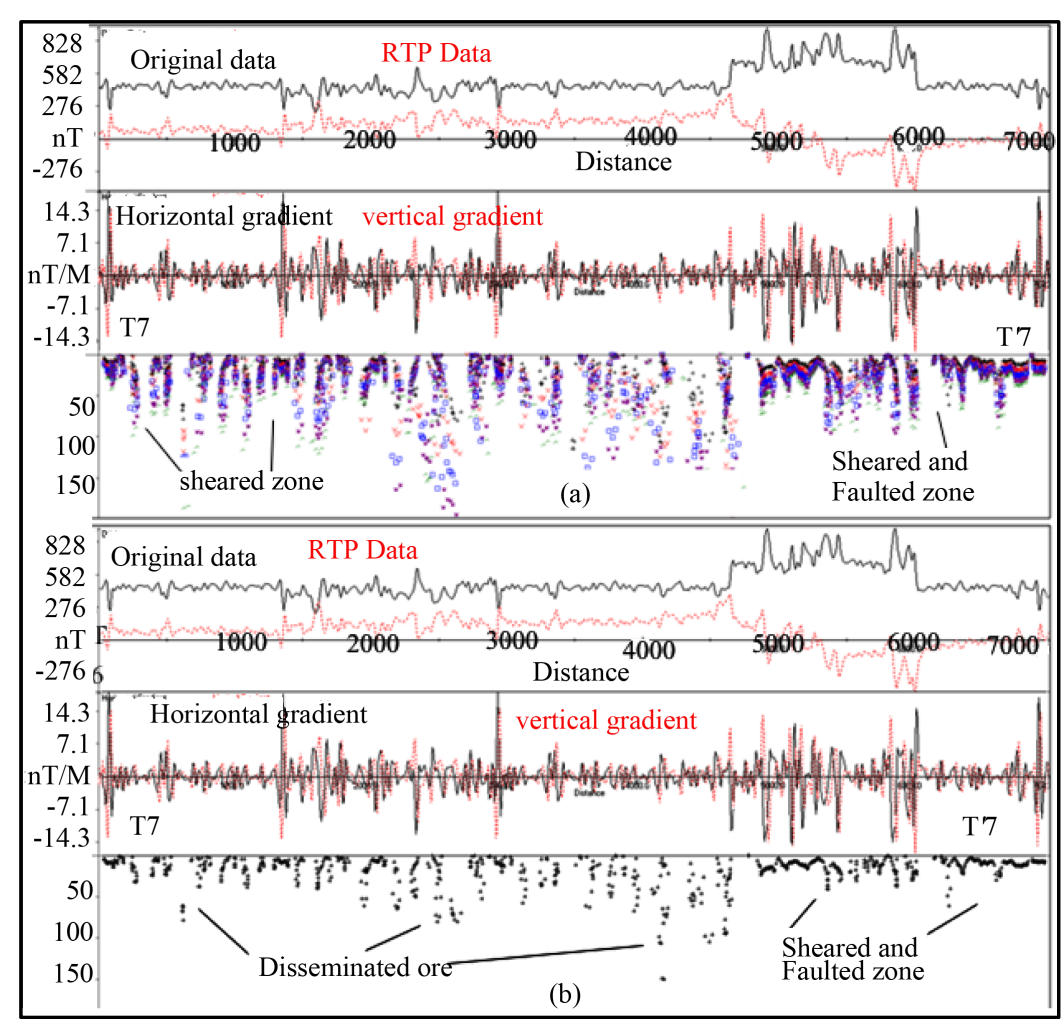

Figure 10. (a) Schematic section of profile T7-T'7 through a sheared and faulted showing the underlying mineralization; (b) Structural index pseudo-section showing faulting and shearing.

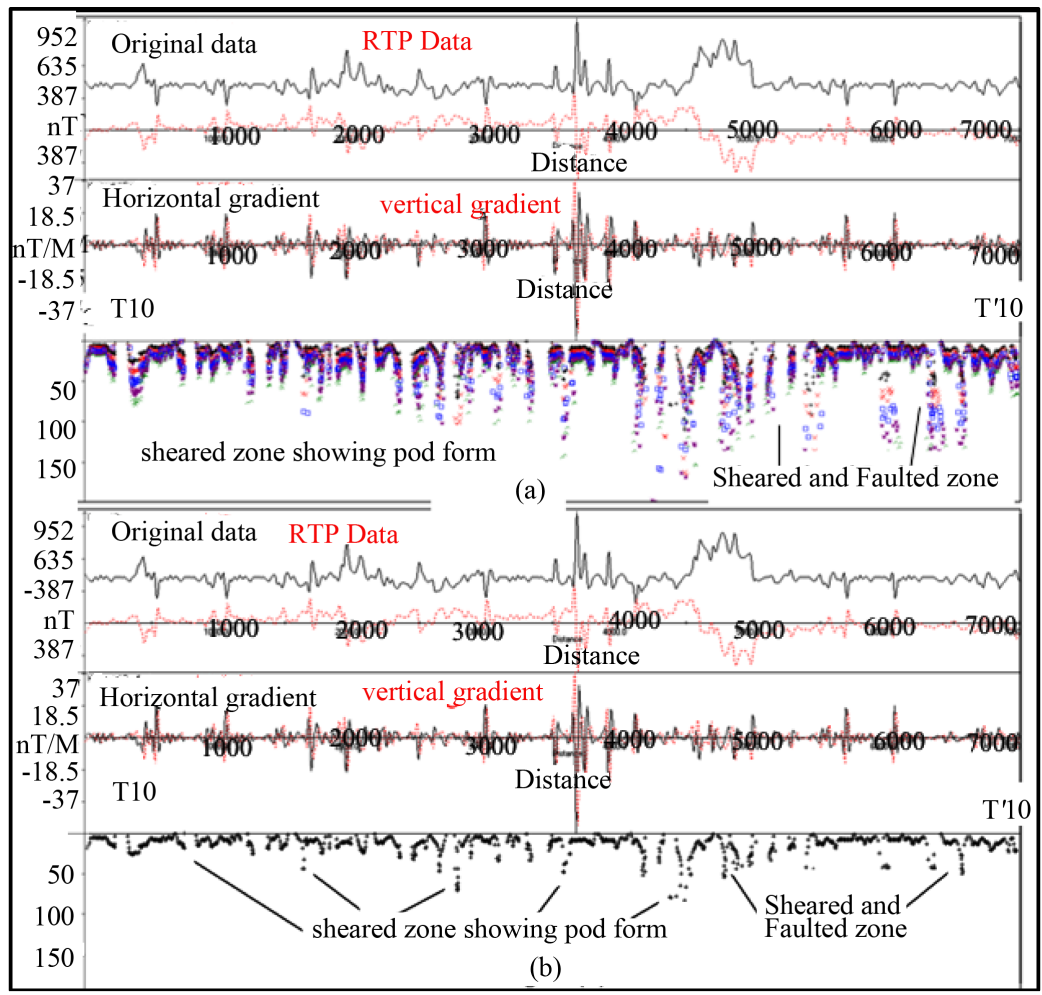

Figure 11. (a) Schematic section of profile $\mathrm{T} 10-\mathrm{T}^{\prime} 10$ through a sheared and faulted showing the underlying mineralization; (b) Structural index pseudo-section showing faulting and shearing. 
Table 1. Chemical analysis of the samples that proved to be Magnetite.

\begin{tabular}{ccccccccccccc}
\hline No. & $\mathrm{SiO}_{2}$ & $\mathrm{Al}_{2} \mathbf{O}_{3}$ & $\mathbf{C a O}$ & $\mathbf{M g O}$ & $\mathbf{N a}_{2} \mathbf{O}$ & $\mathbf{K}_{2} \mathbf{O}$ & $\mathbf{T i O}_{2}$ & $\mathbf{M n O}$ & $\mathbf{F e}_{3} \mathbf{O}_{4}$ & $\mathbf{P}_{2} \mathbf{O}_{5}$ & Total & Mineral \\
\hline 1 & 2.91 & 0.60 & 8.40 & 0.24 & 0.17 & 0.030 & 0.05 & 0.400 & 81.30 & 5.70 & 99.80 & Magnetite + Apt \\
2 & 3.83 & 0.76 & 3.77 & 0.20 & 0.14 & 0.030 & 0.30 & 0.400 & 86.10 & 4.10 & 99.63 & Magnetite + Apt \\
3 & 6.97 & 1.47 & 0.99 & 0.19 & 0.17 & 0.030 & 0.18 & 0.400 & 88.30 & 1.00 & 99.70 & Magnetite \\
4 & 5.05 & 0.33 & 0.25 & 0.30 & 0.12 & 0.030 & 20.70 & 0.600 & 71.00 & ND & 98.38 & Magnetite + Sphene \\
5 & 4.78 & 0.11 & 0.60 & 0.47 & 0.11 & 0.03 & 21.70 & 0.60 & 70.70 & 0.50 & 99.60 & Magnetite + Sphene \\
\hline
\end{tabular}

hornblende gneiss. Shearing along the western part of the area, especially within Tiva, gneisses creates room for iron ore deposition. Iron vein trending in the North-South direction on the western part of the area occurs within the shear zone.

\section{References}

[1] Hildenbrand, T.G., Stuart, W.D. and Talwani, P. (2001) Geological Structures Related to New Madrid Earthquakes near Memphis, Tennessee, Based on Gravity and Magnetic Interpretations. Environment Geology, 62, 105-121. http://dx.doi.org/10.1016/S0013-7952(01)00056-4

[2] Carmichael, R.S. (1982) Magnetic Properties of Minerals and Rocks. In: Carmichael, R.S., Ed., Handbook of Physical Properties of Rocks, Volume II, CRC Press, Boca Raton, 345 p.

[3] Clark, D.A. (1997) Magnetic Petrophysics and Magnetic Petrology: Aids to Geological Interpretation of Magnetic Surveys. AGSO Journal of Australian Geology and Geophysics, 17, 83-103.

[4] Telford, W.M., Geldart, L.P., Sheriff, R.E. and Keys, D.A. (1976) Applied Geophysics. Cambridge University Press, Cambridge, 770.

[5] Holmes, A. (1951) The Sequence of Precambrian Orogenic Belts in Southern and Central Africa. XVIII International Geological Congress, 14, 254-269.

[6] Kennedy, W. (1964) The Structural Differentiation of Africa in the Panafrican Tectonic Episode. 8th Annual Report of the Research Institute for African Geology, Univesity of Leeds, 48-49.

[7] Kazmin, V. (1972) Some Aspects of Precambrian Development in East Africa. Nature, 237, 158-160. http://dx.doi.org/10.1038/237160a0

[8] Kröner, A. (1991) African Linkage of Precambrian Sri Lanka. Geologische Rundschau, 80, 429-440. http://dx.doi.org/10.1007/bf01829375

[9] Cartier, L.E. (2009) Livelihoods and Production Cycles in the Malagasy Artisanal Ruby Sapphire Trade: A Critical Examination. Resources Policy, 34, 80-86. http://dx.doi.org/10.1016/j.resourpol.2008.02.003

[10] Muhongo, S. (1994) Neoproterozoic Collision Tectonics in the Mozambique Belt of East Africa: Evidence from Ulunguru Mountains, Tanzania. Journal of African Earth Sciences, 19, 153-168. http://dx.doi.org/10.1016/0899-5362(94)90058-2

[11] Burke, K. and Derwey, J. (1972) Orogeny in Africa. 3rd Edition, Ibadan University Press, Ibadan, 583-608.

[12] Gass, I. (1977) The Evolution of the Pan African Crystalline Basement in NE Africa and Arabia. Journal of the Geological Society of London, 134, 129-138. http://dx.doi.org/10.1144/gsjgs.134.2.0129

[13] Key, R., Charsley, T.J., Hackman, B.D., Wilkinson, A.F. and Rundle, C.C. (1989) Superimposed Upper Proterozoic Collision Controlled Orogenies in the Mozambique Belt of Kenya. Precambrian Research, 44, 197-225. http://dx.doi.org/10.1016/0301-9268(89)90045-4

[14] Stern, J.R. (1994) Arc Assembly and Continental Collision in the Neoproterozoic East African Orogeny: Implication for the Consolidation of Gondwanaland. Annual Review of Earth and Planetary Sciences, 22, 319-351. http://dx.doi.org/10.1146/annurev.ea.22.050194.001535

[15] Waswa, A.K., Nyamai, C.M., Mathu, E.M. and Ichang'i, D.W. (2015) Integration of Geological Mapping and Remote Sensed Studies for the Discovery of Iron-Ore Mineralization in Mutomo-Ikutha Area, SE Kenya. Universal Journal of Geoscience, 3, 39-50.

[16] Mathu, E.M. and Tole, M.P. (1984) Geology of the Ithanga Hills Area. Journal of African Earth Sciences, 2, 1-16.

[17] Mathu, E.M. (1992) The Mutito and Ikoo faults in the Pan-African Mozambique Belt, Eastern Kenya. In: Mason, R., Ed., Basement Tectonics, Kluwer Academic Publishers, The Netherlands, 61-69. http://dx.doi.org/10.1007/978-94-017-0833-3_5 
[18] Mathu, E.M., Ngecu, W.M., Nyamai, C.M. and Davies, T.C. (1991) Proterozoic Island Tectonism in the Kenyan Mozambique Belt East of Nairobi. In: Muhongo, S., Ed., Proceedings of the International Geological Field Conference on the Mozambique Belt in East Africa, Tanzania, UNESCO, Nairobi, Vol. 8, 59.

[19] Mathu, E.M., Ichang'i, D. and Dindi, E.W. (1994) The Geology, Structures and Tectonics of the Mozambique Belt in Kajiado District, S.W. Kenya. In: Muhongo, S., Ed., Proceedings of the International Geological Field Conference on the Mozambique Belt in East Africa, IGCP 348 Field Meeting in Arusha, Tanzania and Voi, Kenya, UNESCO, Nairobi, 24-25.

[20] Gaciri, S.J., Altherr, R., Nyamai, C.M. and Mathu, E.M. (1993) Distribution of Elements in Mineral Pairs from Mozambique Belt Rocks of Matuu Area, Central Kenya. In: Opiyo-Akech, N. (1984 Edition), Proceedings of the 5th Conference on the Geology of Kenya-Geology for Sustainable Development, UNEP/UNESCO, Nairobi, 57-62.

[21] Biyajima, K., Suswa, K. and Miyakawa, K. (1975) Mantled Gneiss Dome in the Mozambique Belt around Machakos Area, Kenya. Preliminary Report of African Studies, Nagoya University, 6-13.

[22] Suwa, K., Suzuki, K., Miyakawa, K. and Agata, T. (1979) Vanadium and Vanadium Grossulars from the Mozambique Metamorphic Rocks, Mgama Ridge, Kenya. 4th Preliminary Report of African Studies, Nagoya University, 87-96.

[23] Opiyo-Akech, N. and Nyambok, I.O. (1984) Precambrian Geology of the Ishiara Area, Kenya. Journal of African Earth Sciences, 2, 61-65.

[24] Hackman, B.D., Charsley, T.J., Kagasi, J., Key, R.M., Siambi, W.S. and Wilkinson, A.F. (1989) Geology of the Isiolo Area Report. Geological Survey of Kenya, No. 103, 88 p.

[25] Mosley, P. (1993) Geological Evolution of the Late Proterozoic “Mozambique Belt” of Kenya. Journal of Tectonophysics, 221, 223-250. http://dx.doi.org/10.1016/0040-1951(93)90334-G

[26] Nyamai, C.M. (1995) Petrography and Geochemical of Mozambique Belt Rocks of the Matuu Area, Central Kenya. Geology for Sustainable Development, Newsletter/Bulletin 10, UNESCO, 154-155.

[27] Nyamai, C.M., Mathu, E.M. and Ngecu, W.M. (1993) A Review of the Geology of the Mozambique Belt in Kenya. Proceedings of the 9th International Geological Conference of the Geological Society of Africa-Regional Trends in African Geology, Accra, 334-347.

[28] Nyamai, C.M., Opiyo-Akech, N., Gaciri, S.J. and Fujimaki, H. (1999) Geochemistry and Tectonomagmatic Affinities of the Mozambique Belt Intrusive Rocks in Matuu-Masinga Area, Central Kenya. Gondwana Research, 2, 387-399. http://dx.doi.org/10.1016/S1342-937X(05)70278-1

[29] Nyamai, C.M., Opiyo-Akech, N., Gaciri, S.J. and Fujimaki, H. (2000) Structures, Metamorphism and Geochronology of the Mozambique Belt Metamorphic and Intrusive Rocks from Matuu-Masinga Area, Central Kenya. Journal of African Science Technology and Engineering Series, 1, 47-55.

[30] Nyamai, C.M., Opiyo-Akech, N., Gaciri, S.J., Johansson, B. and Sato, Y. (2000) Petrography, Mineral Chemistry and Thermobarometry of the Neoporoterozoic Mozambique Belt Rocks of Matuu-Masinga Area, Central Kenya. In: Mukhopadhaya, D., Ghosh, S.S., Chakrabarti, B.K., Sanyai, S. and Gupta, S.D., Eds., Proceedings of the International Seminar on Precambrian Crust in Eastern and Central India, UNESCO-IUGS-IGCP-368, Journal of Geological Survey of India Special Publication, 57, 296-316.

[31] Nyamai, C.M., Gaciri, S.J., Opiyo-Akech, N., Johansson, B. and Sato, Y. (2002) Conditions of Pyroxene Crystallization and Thermobarometry of the Neoproterozoic Mozambique Belt Intrusive Rocks of Matuu-Masinga Area, Central Kenya. In: Nyamai, C.M. and Maimba, M., Eds., Proceedings of the 8th and 9th Regional Conference of the Geology of Kenya, Geological Society of Kenya, 116-122.

[32] Nyamai, C.M., Mathu, E.M., Opiyo-Akech, N. and Wallbrecher, E. (2003) A Reappraisal of the Geology, Geochemistry, Structures and Tectonics of the Mozambique Belt in Kenya, East of the Rift System. African Journal of Science and Technology Science and Engineering Series, 4, 51-71.

[33] Saggerson (1957) Geology of the Southe Kitui Area, Report 37. Geological Survey of Kenya, 49 p.

[34] Walsh, J. (1963) Geology of Ikutha Area, Report 56. Geological Survey of Kenya, 78 p.

[35] Riddihough, R.P. (1971) Diurnal Corrections to Magnetic Surveys. An Assessment of Errors. Geophysical Prospecting, 19, 551-567. http://dx.doi.org/10.1111/j.1365-2478.1971.tb00900.x

[36] Parasnis, D.S. (1997) Principles of Applied Geophysics. 5th Edition, Chapman and Hall, London, 104-176. 